\title{
Precise engineering of ultrasound-mediated cerium oxide nanoparticles: Investigations on antioxidant, antibacterial activity and human osteomyelitis
}

\section{Xiusong Dai}

First Affiliated Hospital of Bengbu Medical College

\section{Xiaopan Wang}

First Affiliated Hospital of Bengbu Medical College

\section{Xiaotian Chen}

First Affiliated Hospital of Bengbu Medical College

\section{Longfei Ye}

First Affiliated Hospital of Bengbu Medical College

Min Wu ( $\nabla$ min.wu40@yahoo.com )

First Affiliated Hospital of Bengbu Medical College https://orcid.org/0000-0001-8544-6893

\section{Research Article}

Keywords: cerium oxide nanoparticles, antioxidant properties, antibacterial properties, osteomyelitis

Posted Date: February 25th, 2021

DOI: https://doi.org/10.21203/rs.3.rs-238469/v1

License: (9) This work is licensed under a Creative Commons Attribution 4.0 International License. Read Full License 


\section{Abstract}

In this study, the antibacterial activity of cerium oxide nanoparticles on two Gram-negative and three Gram-positive foodborne pathogens was investigated. $\mathrm{CeO}_{2}$ nanoparticles ( $\mathrm{CeO}_{2} \mathrm{NPs}$ ) were synthesized by a Wet Chemical Synthesis route, using the precipitation method and the Simultaneous Addition of reactants (WCS-SimAdd). The as-obtained precursor powders were investigated by thermal analysis (TG-DTA), to study their decomposition process and to understand the $\mathrm{CeO}_{2} \mathrm{NPs}$ formation. The composition, structure, and morphology of the thermally treated sample were investigated by FTIR, Raman spectroscopy, X-ray diffraction, TEM, and DLS. The cubic structure and average particle size ranging between 5 and $15 \mathrm{~nm}$ were evidenced. Optical absorption measurements (UV-Vis) reveal that the band gap of $\mathrm{CeO}_{2} \mathrm{NPs}$ is $2.61 \mathrm{eV}$, which is smaller than the band gap of bulk ceria. The antioxidant effect of $\mathrm{CeO}_{2} \mathrm{NPs}$ was determined, and the antibacterial test was carried out both in liquid and on solid growth media against five pathogenic microorganisms, namely Escherichia coli, Salmonella typhimurium, Listeria monocytogenes, Staphylococcus aureus, and Bacillus cereus. Cerium oxide nanoparticles showed growth inhibition toward all five pathogens tested with notable results. This paper highlights the $\mathrm{CeO}_{2} \mathrm{NPs}$ showed antibacterial activity with significant variations due to the differences in the membrane structure and cell wall composition among the two groups tested. Consequently, synthesized $\mathrm{CeO}_{2} \mathrm{NPs}$ can be potential candidates for the treatment of osteomyelitis.

\section{Highlights}

1. Engineering of cerium oxide nanoparticles $\left(\mathrm{CeO}_{2} \mathrm{NPs}\right)$ with WCS-SimAdd.

2. The composition, structure, and morphology of the thermally treated sample were investigated by FTIR, Raman spectroscopy, X-ray diffraction, TEM, and DLS.

3. Antibacterial efficacy was developed in the Gram-negative and three Gram-positive for $\mathrm{CeO}_{2} \mathrm{NPs}$.

4. The engineered $\mathrm{CeO}_{2} \mathrm{NPs}$ can be potential candidates for the treatment of osteomyelitis.

\section{Introduction}

Osteomyelitis is an inflammation of the bone caused by infective micro-organisms. The usual treatment of osteomyelitis mainly involves fundamental surgical debridement of the infected bone, filling the bone defect, adequate soft tissue coverage and antibiotic therapy [1-4]. A prolonged course of antibiotic therapy is required, most often weeks and sometimes longer. The oral delivery of antibiotics can result in systemic toxicity associated with renal and liver complications and poor penetration into the targeted site. Hence, an alternative strategy of antibiotic delivery should be explored [5-8]. Recently, development of a local drug delivery system received much attention since antibiotics are delivered locally, the side effects and the risk of overdose of oral administration can be avoided and high concentration of drugs can effectively reach the targeted site. Bioactive materials in combination with antibiotics are very useful 
for the development of local drug delivery systems because they play a vital role in subsequent bone regeneration at the infected site [9-12].

Antibiotics or antimicrobials have been widely utilized in various fields, such as medicine, food industry, agriculture, livestock, water treatment for diseases prevention, and pathogens eradication [13-15]. Nevertheless, there is an increased concern related to multidrug-resistant microorganisms. Worldwide, numerous scientists direct their efforts toward finding new alternatives for combating pathogens [16-18]. Among the many alternatives, such as plant extracts, antimicrobial peptides, and bee products, metal or metal oxide nanoparticles are recently receiving increased attention [19-22]. The properties found in the nanoparticle form of these materials can significantly differ from those of their bulk tantamount. Specific properties, such as considerably high contact surface and selectivity in the mediation of chemical transformations, facilitate their use in various areas. Nanoparticles with various morphologies are utilized in multiple areas, including medicine, for the treatment or diagnosis of pathogen-fighting systems or improvement of the fuel quality [23-25].

Metal oxide nanoparticles, such as $\mathrm{CeO}_{2}$, have significant action on the antimicrobial activity and offer the plausibility of efficient pathogen removal from different environments. Furthermore, the stability and the slow release of metal ions from the nanoparticles are key features which make their usage advantageous [26-29]. In comparison to other metal oxide nanoparticles, $\mathrm{CeO}_{2}$ has the quality of being an antioxidant due to the reversibility of its transfer from the reduced state into the oxidized state and resumes the process. Its uses as an abrasive in semiconductor fabrication, or as a component in catalytic converters for auto machines exhaust systems, as a fuel additive to boost combustion, as an electrolyte for fuel, and as a UV-light absorber are also well-known [30-34]. Recently, nanoceria has been used as a colorimetric indicator for antioxidants activity due to the color changes induced by the modifications of cerium oxidation states at nanoparticle surface. It was established that $\mathrm{CeO}_{2} \mathrm{NPs}$ have the capacity to initiate their mechanism by the modulation of the oxygen environment. The properties of these $\mathrm{CeO}_{2} \mathrm{NPs}$ prove important possible biomedical applications. Scattered literature regarding the antibacterial activity of $\mathrm{CeO}_{2} \mathrm{NPs}$ is available $[18,35,36]$. The effect against $E$. coli and $B$. subtilis a comparison of the antibactericidal activity of bulk and nano $\mathrm{CeO}_{2} \mathrm{NPs}$ against the same Gram-negative bacteria and cytotoxicity on nitrogen-fixing bacteria are reported. Many studies have reported the synthesis of ceria nanoparticles ( $\mathrm{CeO}_{2} \mathrm{NPs}$ ), using different cerium salts (acetate or nitrate) and different reactants (citric acid, ammonia, or hydrogen peroxide), and organic solvents/stabilizers (oleic acid, oleylamine, or diphenyl ether) to prevent particle agglomeration. The addition of these organic species to the aqueous solution directly affects the stabilization level, the nucleation, and the growth processes of the $\mathrm{CeO}_{2} \mathrm{NPs}$ in the homogeneous solutions [37-41].

The aim of our work was the investigation of antibacterial properties of $\mathrm{CeO}_{2} \mathrm{NPs}$ against a wider range of pathogens, namely Escherichia coli, Salmonella typhimurium, Listeria monocytogenes, Staphylococcus aureus, and Bacillus cereus. A simple, reproducible, controllable, and low-cost wet-chemical synthesis method was used for the preparation of $\mathrm{CeO}_{2} \mathrm{NPs}$. This precipitation-type method consists of the 
simultaneous addition of reactants (SimAdd) in the presence of an anti-agglomeration agent, under $\mathrm{pH}$ control, with the formation of cerium oxalate type salt as a precursor. Based on the precursor characterization-thermal analysis and FTIR-the particle dimensionality and aggregation can be controlled. The $\mathrm{CeO}_{2} \mathrm{NPs}$ were characterized by using spectroscopic and microscopic methods, and their antioxidant and antibacterial activity was tested on two Gram-negative and three Gram-positive pathogens, respectively.

\section{Experimental Section}

\subsection{Materials}

The chemicals used in the synthesis of the $\mathrm{CeO}_{2} \mathrm{NPs}$ are cerium nitrate hexahydrate, $\mathrm{Ce}\left(\mathrm{NO}_{3}\right)_{3} \cdot 6 \mathrm{H}_{2} \mathrm{O}$ (Sigma Aldrich, Chemie GmbH, Taufkirchen, Germany)-cation source, oxalic acid dihydrate, and $\mathrm{H}_{2} \mathrm{C}_{2} \mathrm{O}_{4} \cdot 2 \mathrm{H}_{2} \mathrm{O}$ (Alfa Aesar, Thermo Fisher Scientific Chemicals, Inc. Ward Hill, MA, USA) - precipitation agent, ammonia solution $\mathrm{NH}_{4} \mathrm{OH}, 30 \% \mathrm{NH}_{3}$ (Alfa Aesar, Thermo Fisher Scientific Chemicals, Inc. Ward Hill, MA, USA) for $\mathrm{pH}$ control, tetraethylammonium hydroxide, $\left(\mathrm{C}_{2} \mathrm{H}_{5}\right)_{4} \mathrm{~N}(\mathrm{OH})$ as an anti-agglomeration agent, and $\mathrm{NH}_{4} \mathrm{Cl}$ (Alfa Aesar, Thermo Fisher Scientific Chemicals, Inc. Ward Hill, MA, USA) as flux. All chemicals were reagent grade and used without further purification.

\subsection{Synthesis of cerium oxide nanoparticles $\left(\mathrm{CeO}_{2} \mathrm{NPs}\right)$}

The $\mathrm{CeO}_{2} \mathrm{NPs}$ samples were prepared via the Wet-Chemical Synthesis route, which consists of the Simultaneous Addition of reagents technique (WCS-SimAdd), using cerium nitrate and oxalic acid 50 $\mathrm{mM}$ aqueous solutions. The chemical reaction is presented in the Supplementary Materials file. The precipitation was carried out under continuous magnetic stirring, and the $\mathrm{pH}$ value was adjusted to $7 \pm$ 0.2 by adding the ammonium hydroxide. Moreover, a small amount (1 vol\%) of tetraethylammonium hydroxide solution was added to prevent the agglomeration of the particles. The post-precipitation stage consisted of $24 \mathrm{~h}$ aging, separation by filtering, and drying. The precursor nano-powders were intimately mixed with $\mathrm{NH} 4 \mathrm{Cl}$ (flux), and the thermal treatment was performed at $400^{\circ} \mathrm{C} / 1 \mathrm{~h}$, in air, at a heating rate of $300{ }^{\circ} \mathrm{C} / \mathrm{h}$. The thermally treated powders were washed several times with distilled water, until the filtrate was $\mathrm{Cl}-$ free. The solution was heated at $80^{\circ} \mathrm{C}$ in an oven till half of its volume. The precursor was then kept in the microwave oven, operated at a power of $800 \mathrm{~W}$ with the frequency $2450 \mathrm{MHz}$ for $10 \mathrm{~min}$. A yellowish brown precipitate started to appear which suggested the formation of cerium oxide nanoparticles. A yellow aqueous solution ( $2 \mathrm{mM}$ ) was obtained by dispersing a specific mass of ceria nps in distilled water.

\subsection{Characterization of cerium oxide nanoparticles $\left(\mathrm{CeO}_{2} \mathrm{NPs}\right)$}

The thermal decomposition process of cerium oxalate-type precursor was monitored by thermal analysis, using a Mettler Toledo TGA/SDTA851 (Greifensee, Switzerland) system, a platinum crucible, and a heating rate of $10 \mathrm{~K} / \mathrm{min}$, in a static air atmosphere up to $500{ }^{\circ} \mathrm{C}$. The chemical nature of the 
precursor and final oxide was analyzed by Fourier Transform Infrared Spectroscopy (FTIR), using a Tensor 27 Bruker FTIR spectrophotometer (Bruker Optik GmbH, Germany). The crystalline structure of the $\mathrm{CeO}_{2}$ NPs-powders was determined by X-ray diffraction (XRD) investigations, which were performed at room temperature, by means of a Bruker AXS D8 Discover diffractometer (Bruker, Karlsruhe, Germany) operating at $40 \mathrm{kV}, 40 \mathrm{~mA}$, CuKa radiation $\lambda=1.54056 \AA$. The hydrodynamic diameter was determined by dynamic light scattering (DLS) measurements, using a Brookhaven Instruments Corporation (Holtsville, NY, USA), a goniometer, and a laser light-scattering system. The acquisition time was set to $90 \mathrm{~s}$, a laser radiation wavelength of $632.8 \mathrm{~nm}$ was used, and the angle at which data acquisition was performed was $90^{\circ}$. During long-term storage, the solution gradually lost its stability due to the formation of nanoparticle aggregates. TEM was utilized to characterize the morphology of $\mathrm{CeO}_{2}$ NPs. A JEOL JEM1010 transmission electron microscope (JEOL USA, Inc., Peabody, MA, USA) was used, operating at an accelerating voltage of $100 \mathrm{kV}$ and equipped with a MegaViewIII CCD camera. The optical characterization was performed by a Jasco V 530 spectrophotometer (Jasco Corporation, Tokyo, Japan), in the range of 200-800 nm. The Raman spectra of the $\mathrm{CeO}_{2} \mathrm{NPs}$ were recorded at room temperature, using a Renishaw in Via Reflex Raman Microscope (New Mills, UK) equipped with a RenCam CCD detector. The Raman system was operated with $532 \mathrm{~nm}$ laser line, and the spectra were recorded by adding 4 accumulations, each with a 40 s exposure time, acquired by using $13.5 \mathrm{~mW}$ laser power with a 4 $\mathrm{cm}^{-1}$ resolution.

\subsection{Antioxidant properties of $\mathrm{CeO}_{2} \mathrm{NPs}$ scavenging effect on ABTS radicals}

The scavenging properties of $\mathrm{CeO}_{2} \mathrm{NPs}$ against radical cations $\mathrm{ABTS}^{+}\left(2,2^{\prime}\right.$-azino-bis(3ethylbenzothiazoline-6-sulfonic acid)) were determined according to the procedure described in other studies $[19,42,43]$, adapted to a microplate of 96 wells. The ABTS assay is based on the capacity of a sample to scavenge the ABTS radical cation (ABTS. $\left.A B T S^{+}\right)$, as compared to a standard antioxidant (Trolox). The blue-green $\mathrm{ABTS}^{+}$solution was produced by the reaction between a $7 \mathrm{mM}$ aqueous solution of ABTS and a $2.45 \mathrm{mM}$ potassium persulfate, in a dark medium, and at room temperature, for 12-16 $\mathrm{h}$ before use. ABTS + working solution was obtained by diluting the stock solution with ethanol, resulting in an absorbance of $0.70 \pm 0.02 \mathrm{AU}$ at $734 \mathrm{~nm}$. Then, $20 \mu \mathrm{L}$ of Trolox or $\mathrm{CeO}_{2} \mathrm{NPs}$ solution at different concentrations were added to $170 \mu \mathrm{L} \mathrm{ABTS}^{+}$solutions, and the absorbance was measured after 6 min of incubation, in the dark, and at room temperature, using a microplate reader. The results were expressed as $\mu \mathrm{mol}$ Trolox per Gram sample.

\subsection{Antibacterial activity of cerium oxide nanoparticles $\left(\mathrm{CeO}_{2} \mathrm{NPs}\right)$}

The antibacterial activity of the tested nanoparticles was evaluated by using different methods [44-46], such as disk diffusion tests, UV-Vis measurements of the optical density (OD), the number of colonyforming units (CFUs) on solid medium, the resazurin test, and bacterial viability, using confocal microscopy. The five pathogenic strains used in the study were Escherichia coli ATC 25922 
(Microbiologics), Salmonella typhimurium ATCC 14028 (Microbiologics) Listeria monocytogenes ATCC 35152 (Liofilclem), Staphylococcus aureus ATCC 65389 (MediTech), and Bacillus cereus ATCC 11778 (MediTech).

\subsection{Disk diffusion method}

About $15 \mathrm{~mL}$ of sterile nutrient agar (Bioaqua, Targu-Mures) was poured into the sterile Petri dish. Triplicate plates were inoculated with $200 \mu \mathrm{L}$ of the overnight culture (approximately $108 \mathrm{CFU} / \mathrm{mL}$ ) of the targeted pathogenic bacteria, which were spread on the plate, using sterile Drigalski spatulas. On the solid medium were gently placed up to 6 paper disks that were soaked with a fixed concentration of $\mathrm{CeO}_{2} \mathrm{NPs}$ solution. The plates were incubated for $24 \mathrm{~h}$ at $37 \pm 1{ }^{\circ} \mathrm{C}$, prior to the determination of results. The zone of inhibition around each of the paper disks was measured and expressed as millimeters in diameter. Gentamicin was used as the control [47-49].

\subsection{Minimum inhibitory concentration (MIC)}

Broth dilution tests were conducted in standard trays containing 96 wells, to evaluate the MIC of the cerium oxide nanoparticles. To obtain sequential dilutions, $150 \mu \mathrm{L}$ of the cerium oxide nanoparticles was homogenized with $150 \mu \mathrm{L}$ of nutrient broth; afterward, the solution was well mixed, and then $150 \mu \mathrm{L}$ of the mixture was transferred in the next well containing $150 \mu \mathrm{L}$ of nutrient broth. The final volume was of $200 \mu \mathrm{L}$ in each well after the addition of $50 \mu \mathrm{L}$ of 24 -hour-old bacteria inoculum. The final solution was allowed to grow at $37^{\circ} \mathrm{C}$ for $24 \mathrm{~h}$. Growth curves for the control of pathogenic cells incubated with three different concentrations of $\mathrm{CeO}_{2}$ NPs were measured at OD550. The MIC value was the lowest concentration of the nanoparticles that did not permit any visible growth of the pathogenic bacteria during $24 \mathrm{~h}$ of incubation because of turbidity. The negative control was the sample where no bacteria were added, and the positive control was the sample where no cerium oxide nanoparticles were added. The turbidity was measured by using UV-Vis spectroscopy (microplate reader (HT BioTek Synergy) at $550 \mathrm{~nm}$. The same experiment was conducted, using gentamicin as an antibiotic. All the experiments were performed in triplicates and were repeated twice [50-52].

\subsection{Minimum bactericidal concentration (MBC)}

To prevent the possibility of misinterpretation due to the turbidity of insoluble compounds, the MBC was established by sub-culturing the above (MIC) serial dilutions after the incubation time in nutrient agar plates, using a $0.01 \mathrm{~mL}$ loop, and further incubating the dilutions at $37^{\circ} \mathrm{C}$ for $24 \mathrm{~h}$. The MBC was considered to be the lowest concentration that prevents the growth of the bacterial colony on this solid medium [53-55].

\subsection{Bacterial viability using confocal microscopy}

The confocal laser scanning microscope - Zeiss LSM 710 (Oberkochen, Germany) - is a method that allowed us to view live and dead bacteria. Bacteria cells culture ( $108 \mathrm{CFU})$ were treated with $50 \mu \mathrm{g} / \mathrm{mL}$ 
of $\mathrm{CeO}_{2} \mathrm{NPs}$ for $24 \mathrm{~h}$. A control with no treatment was made for each pathogen. Prior to the confocal microscopy assay, the bacteria cells were mixed, for coloration, with a LIVE/DEAD ${ }^{8}$ BacLight $^{\text {TM }}$ bacterial viability Kit, L-7007, for $15 \mathrm{~min}$, in the dark. Aliquots of $50 \mu \mathrm{L}$ of the colored bacteria were placed on a microscope slide, fixed using a flame, rinsed, and dried.

\subsection{Time kill assay}

The potential $\mathrm{CeO}_{2} \mathrm{NPs}$ was subject to the time killing assay. An inoculum of the tested pathogens (10 $\mu \mathrm{L}$ ), at a concentration of $108 \mathrm{CFU} / \mathrm{mL}$, was mixed with $100 \mu \mathrm{L}$ of solution containing growth medium and nanoparticles, to a final concentration of $50 \mu \mathrm{g} / \mathrm{mL}$. The negative controls were the samples in which no nanoparticles were utilized. The growth of bacterial species was assessed at every $1 \mathrm{~h}$ interval, by measuring the optical density at $550 \mathrm{~nm}$ with the microplate reader [56-58].

\section{Results And Discussion}

It is well-known that the critical step in the synthesis of metal oxide by wet-chemical methods is the thermal decomposition of the obtained precursor [59-61]. The thermal analysis method (DTA-TG) allowed us to investigate the chemical transformation of the oxalate-type precursor into oxide powders during heating (Figure 1a and $\mathbf{b}$ ). The thermal behavior of the synthetized precursor through simultaneous DTA-TG measurements reveals two weight-loss processes. In the low temperature range, the DTA curve illustrates an endothermic process with the maximum temperature centered around $150{ }^{\circ} \mathrm{C}$, accompanied by a mass loss of $23.8 \%$ on the TG curve. This first decomposition step is attributed to the dehydration of the precursor with the loss of around 10 water molecules and the formation of anhydrous cerium oxalate. The second weight loss $(\sim 28.5 \%)$ is observed at temperatures ranging between 250 and $350^{\circ} \mathrm{C}$ and corresponds to the oxidative decomposition of the oxalate group, as indicated by the exothermic effect, whose maxima is located at $298^{\circ} \mathrm{C}$. Almost no weight loss is observed at temperatures higher than $350^{\circ} \mathrm{C}$ in the TG curve, indicating that the oxalate precursor was completely decomposed with the formation of $\mathrm{CeO}_{2} \mathrm{NPs}$. This decomposition behavior confirms that the chemical composition of the oxalate precursor is close to the molecular formula of $\mathrm{Ce}_{2}\left(\mathrm{C}_{2} \mathrm{O}_{4}\right)_{3} \cdot 10 \mathrm{H}_{2} \mathrm{O}$, which is in concordance with the literature data. Based on these observations, one can assume that the precursor decomposition takes place according to the following chemical reactions:

100-200 ${ }^{\circ} \mathrm{C}: \mathrm{Ce}_{2}\left(\mathrm{C}_{2} \mathrm{O}_{4}\right)_{3} \cdot 10 \mathrm{H}_{2} \mathrm{O} \rightarrow \mathrm{Ce}_{2}\left(\mathrm{C}_{2} \mathrm{O}_{4}\right)_{3}+10 \mathrm{H}_{2} \mathrm{O}$

$250-350^{\circ} \mathrm{C}: \mathrm{Ce}_{2}\left(\mathrm{C}_{2} \mathrm{O}_{4}\right)_{3} \rightarrow 2 \mathrm{CeO}_{2}+2 \mathrm{CO}_{2}+4 \mathrm{CO}$

To identify the crystalline phases and to estimate the average particle sizes, an XRD investigation was performed. The XRD pattern of the oxide powders obtained after annealing at $400{ }^{\circ} \mathrm{C}$ for $1 \mathrm{~h}$ is presented in Figure 1c. All the reflections were indexed with those of the pure cubic fluorite structure of $\mathrm{CeO} 2$ (JCDD PDF 034-0394). The average crystallite sizes of the sample were calculated by using the Debye-Scherrer 
formula: $D p=0.9 . \lambda / \beta \cos \theta$, where $D p$ is the average crystallite size, $\lambda$ is the wavelength of the CuKa line, $\theta$ is the Bragg angle, and $\beta$ is the Full Width at Half-Maximum (FWHM) of the diffraction peak in radians. The average crystallite size calculated for (111), (200), (220), and (311) reflections was about $7 \mathrm{~nm}$.

To further analyze the morphology size and shape of $\mathrm{CeO}_{2}$ NPS, TEM-HRTEM and DLS characterizations were carried out, and the results are presented in Figure $2 a-b$. The TEM images illustrate the presence of aggregates with pseudo-spherical shapes. This behavior to form larger and denser nanoparticle aggregates during the thermal treatment is characteristic for oxalate-type precursors. DLS measurements of the $\mathrm{CeO}_{2} \mathrm{NPs}$ suspensions present an average hydrodynamic diameter (Dh) of $9.65 \mathrm{~nm}$, with the size of the nanoparticles averaging in the range of 5-20 nm. This larger value for $\mathrm{Dh}$ is related to the interference of the dispersant into the hydrodynamic diameter.

Figure 3a shows the FTIR spectra of the synthetized $\mathrm{CeO}_{2} \mathrm{NPs}$ and the cerium oxalate-type precursor. The large band observed in the $3500-3000 \mathrm{~cm}^{-1}$ domain can be assigned to the collective in-phase symmetric $_{v}(\mathrm{O}-\mathrm{H})$ stretching vibration. The asymmetric ${ }_{\text {vasym }}\left(\mathrm{COO}^{-}\right)$observed at $1598 \mathrm{~cm}^{-1}$ and the symmetric $_{\text {vsym }}\left(\mathrm{COO}^{-}\right)$stretching modes observed 1356 and $1308 \mathrm{~cm}^{-1}$ are assigned to the oxalate modes. The difference in their frequencies, ${ }_{\Delta v}\left(\mathrm{COO}^{-}\right)={ }_{\text {vasym }}\left(\mathrm{COO}^{-}\right)_{\text {vsym }}\left(\mathrm{COO}^{-}\right)$, is around $298 \mathrm{~cm}^{-1}$ and is indicative of the formation of a bidentate coordination bond between the cerium ions and the oxalate group. Moreover, the low-intensity vibration bands at 1460 and $1418 \mathrm{~cm}^{-1}$ suggest the existence of both mononuclear and binuclear bidentate oxalate complexes. The low intensity band observed at $1095 \mathrm{~cm}^{-1}$ is characteristic for ${ }_{\text {vas }}(\mathrm{C}-\mathrm{O}-\mathrm{C})$ and ${ }_{\mathrm{v}}(\mathrm{Ce}-\mathrm{O}-\mathrm{C})$ vibration. The bands at 795,485 , and $365 \mathrm{~cm}^{-1}$ are attributed to the ${ }_{\delta}(\mathrm{O}-\mathrm{C}=0)$ bridging oxalate group and to the interaction of the metal-oxygen vibration v $(\mathrm{Ce}-0)$. The FTIR spectrum of $\mathrm{CeO}_{2} \mathrm{NPs}$ confirms the total conversion of the oxalate precursor into ceria by thermal treatment. The presence of the absorption bands characteristic to $\mathrm{Ce}-\mathrm{O}$ vibrations sustains the main phase of the as-prepared particles as cerium oxide, and the thermal treatment assures the complete decomposition of the oxalate-type precursor.

Raman spectroscopy is one of the major tools utilized in the study of crystallinity, purity, and any defect levels connected to the nanomaterials. A typical Raman spectrum for bulk $\mathrm{CeO}_{2} \mathrm{NPs}$ with cubic fluorite structure presents a single strong peak at $464 \mathrm{~cm}^{-1}$, assigned to the $\mathrm{F}_{2 \mathrm{~g}}$ symmetry modes of $\mathrm{CeO}_{2} \mathrm{NPs}_{\text {. }}$ The Raman spectrum of the synthetized $\mathrm{CeO}_{2} \mathrm{NPs}$ (Figure $3 \mathbf{b}$ ) exhibits a strong Raman absorption peak at $461 \mathrm{~cm}^{-1}$ and two weak absorption peaks at 610 and $740 \mathrm{~cm}^{-1}$. The Raman peak at $461 \mathrm{~cm}^{-1}$ corresponds to the triply degenerate $F_{2 g}$ mode of symmetric stretching vibration of oxygen ions around $\mathrm{Ce}^{4+}$ cations and therefore confirms the cubic fluorite structure. The slight broadness of the peak is attributed to the reduction of the particle size to nanometric ranges. The shift in the peak position toward 
the lower energy value and the broad peaks at 610 and $740 \mathrm{~cm}^{-1}$ are due to the presence of point defects generated by oxygen vacancies.

The UV-Vis spectrum is shown in Figure 4. The maximum absorption peak at $350 \mathrm{~nm}$ is assigned to the charge transfer between the $\mathrm{O} 2 \mathrm{p}$ and $\mathrm{Ce} 4 \mathrm{f}$ states in $\mathrm{O}^{2-}$ and $\mathrm{Ce}^{4+}$. Compared with $\mathrm{CeO}_{2} \mathrm{NPs}$ bulk, where the absorption peak is around $389 \mathrm{~nm}$, the maximum intensity for the synthetized $\mathrm{CeO}_{2} \mathrm{NPs}$ is shifted toward a lower wavelength value (blueshift). Based on the absorption spectra, the direct band gap of $\mathrm{CeO}_{2} \mathrm{NPs}$ was determined from the following relationship: ahv $=\mathrm{A}(\mathrm{hv}-\mathrm{Eg})^{\mathrm{n} / 2}$, where $a$ is the optical absorption coefficient, $a=A / d^{\prime} ; A$-is the measured absorbance, and $d^{\prime}$ is the thickness of sample in a UV-Vis cell $(0.4 \mathrm{~cm})$; hv is the photon energy; and Eg is the direct band gap of the sample. The extrapolation of the linear part of the domain of (ahv)2 vs. hv to the ahv $=0$ (where hv $=\mathrm{Eg}$ ) allows the determination of the direct band gap of Eg value $(2.61 \mathrm{eV})$. The red shift in the band gap is associated with oxygen vacancies and existence of $\mathrm{Ce}^{3+}$ to the nanoparticle surface. Oxygen defects and $\mathrm{Ce}^{3+}$ ions generate intermediate defect energy states in the $\mathrm{CeO}_{2}$ band gap. Due to the presence of these states, the direct transition of electrons from $\mathrm{O} 2 \mathrm{p}$ to $\mathrm{Ce} 4 \mathrm{f}$ is slowed down, resulting in the decrease of band gap value.

To evaluate the antioxidant potential of $\mathrm{CeO}_{2} \mathrm{NPs}$, the ABTS (2,2'-azino-bis(3-ethylbenzthiazoline)-6sulphonic acid) assay was tested. The ABTS method is indicated for a suitable and continuous spectrophotometric measurement of any potential radical formations. ABTS creates a characteristic cation radical $\left(\mathrm{ABTS}^{+}\right)$that can be easily followed and can allow the measurement of the initial rate of radical formation. The obtained results (Figure 5) have clearly demonstrated that the $\mathrm{CeO}_{2} \mathrm{NPs}$ is a radical scavenger and can inhibit the ABTS+ radical formation in a dose-dependent manner. The results were expressed as Trolox equivalents. Trolox is a water-soluble analogue of vitamin E. Trolox is an antioxidant that has been shown to prevent lipid peroxidation in vivo. Previous publications have shown that vitamin $E$ is effective in preventing oxidative harm from iron and other redox-active metals in vivo and in vitro, likely by reacting with hydroxyl radicals or downstream radical intermediates. It can be easily concluded that the antioxidant activity increases in direct proportionality with the nanoparticle concentration.

Compared with bulk, $\mathrm{CeO}_{2} \mathrm{NPs}$ exhibit superior properties due to their small size, which allows a rapid adsorption of pathogens. Many studies have shown that the $\mathrm{CeO}_{2} \mathrm{NPs}$ exhibit excellent antibacterial activity against Gram-positive and Gram-negative bacteria due to the generation of reactive oxygen species (ROS). In healthy cells, $\mathrm{CeO}_{2} \mathrm{NPs}$ act as antioxidants by scavenging ROS at a physiological $\mathrm{pH}$, while, in pathogens-under low-pH environment- $\mathrm{CeO}_{2} \mathrm{NPs}$ act as a pro-oxidant by generating ROS and producing cell damage. 
The antibacterial activity of $\mathrm{CeO}_{2} \mathrm{NPs}$ was evaluated by using the microdilution method, and the corresponding MIC and MBC values were evaluated against two Gram-negative and three Gram-positive pathogens. The correspondent values are given in Table 1 and Table 2, respectively. The cerium oxide nanoparticles demonstrated antibacterial properties against all the tested pathogens in relative low concentrations.

Table 1. Antibacterial activity of $\mathrm{CeO}_{2} \mathrm{NPs}$ at $50 \mu \mathrm{g} / \mathrm{mL}$ and gentamicin $10 \mu \mathrm{g} / \mathrm{mL}$, against pathogenic bacteria.

\begin{tabular}{|c|c|c|c|}
\hline & $\begin{array}{l}\text { Pathogenic } \\
\text { Bacteria }\end{array}$ & $\begin{array}{l}\mathrm{CeO}_{2} \mathrm{NPs} \text { Zone of Inhibition ( } \mathrm{mm} \\
\text { Diameter) }\end{array}$ & $\begin{array}{l}\text { Gentamicin Zone of Inhibition ( } \mathrm{mm} \\
\text { Diameter) }\end{array}$ \\
\hline & Escherichia coli & $9 \pm 0.05$ & $15 \pm 0.43$ \\
\hline G- & $\begin{array}{l}\text { Salmonella } \\
\text { typhimurium }\end{array}$ & $12 \pm 0.02$ & $17 \pm 0.02$ \\
\hline \multirow{4}{*}{ G+ } & \multirow{2}{*}{$\begin{array}{l}\text { Listeria } \\
\text { monocytogenes }\end{array}$} & $10 \pm 0.04$ & $19 \pm 0.01$ \\
\hline & & $5 \pm 0.02$ & $18 \pm 0.02$ \\
\hline & $\begin{array}{l}\text { Staphylococcus } \\
\text { aureus }\end{array}$ & $7 \pm 0.05$ & $16 \pm 0.01$ \\
\hline & Bacillus cereus & & \\
\hline
\end{tabular}

Table 2. Minimum Inhibitory Concentration (MIC) and Minimum Bactericidal Concentration (MBC) of $\mathrm{CeO}_{2} \mathrm{NPs} /$ gentamicin against pathogenic bacteria. Experiments were performed in triplicates and were repeated twice.

\begin{tabular}{|llll|}
\hline Bacterial Strains & $\begin{array}{l}\mathrm{CeO}_{2} \mathrm{NPs} \mathrm{MIC} \\
(\mathrm{mg} / \mathrm{mL})\end{array}$ & $\begin{array}{l}\text { Gentamicin } \mathrm{MIC} \\
(\mathrm{mg} / \mathrm{mL})\end{array}$ & $\begin{array}{l}\mathrm{CeO}_{2} \mathrm{NPs} \mathrm{MBC} \\
(\mathrm{mg} / \mathrm{mL})\end{array}$ \\
\hline Escherichia coli & 2.15 & 3.0 & 2.15 \\
Salmonella typhimurium & 1.07 & 0.38 & 1.07 \\
Listeria monocytogenes & 1.07 & 1.2 & 1.07 \\
Staphylococcus aureus & 10 & 0.83 & 10 \\
Bacillus cereus & 4.3 & 0.39 & 4.3 \\
\hline
\end{tabular}

The antibacterial activity of $\mathrm{CeO}_{2} \mathrm{NPs}$ discloses that the same concentration of nanoparticles against Escherichia coli and Salmonella typhimurium resulted in different diameters of inhibition, with these being 9 and $10 \mathrm{~mm}$, respectively. Regarding the Gram-positive pathogens, the highest inhibition was registered in the case of Listeria monocytogenes, followed by Bacillus cereus and Staphylococcus 
aureus. The $\mathrm{MBC}$ results reveal that the highest sensitivity of solely $1.07 \mathrm{~g} / \mathrm{L} \mathrm{CeO}{ }_{2} \mathrm{NPs}$ can be observed in Salmonella typhimurium and Listeria monocytogenes. The difference in the action of $\mathrm{CeO}_{2} \mathrm{NPs}$ against the Gram-positive and Gram-negative pathogens is primarily related to the different structure and compactness of their cell walls. Usually, Gram-positive bacteria have a thicker, waxy cell wall, making them more resistant to the antimicrobial activity of $\mathrm{CeO}_{2} \mathrm{NPs}$ in comparison with Gram-negative bacteria. For example, the Gram-positive Bacillus cereus has a cell wall of $55.4 \mathrm{~nm}$, while the Gram-negative S. typhimurium has a cell wall of only $2.4 \mathrm{~nm}$. Even if important functional differences can be seen between the Gram-positive and Gram-negative bacteria cell wall, in the DNA-based molecular taxonomy, some pathogens have a similar response to the same antibacterial agents.

The antibacterial effect of $\mathrm{CeO}_{2} \mathrm{NPs}$ is confirmed by the confocal microscopy images from Figure 6 and 7. The results clearly evidence that the inhibitory effect of $\mathrm{CeO}_{2} \mathrm{NPs}$ is present at a lower concentration, with respect to gentamicin (the standard drug). This fact guarantees the presence of the antibacterial action of $\mathrm{CeO}_{2} \mathrm{NPs}$ against the tested pathogens.

The time kill assay shows an inhibitory effect in a time-dependent manner, in Figure $\mathbf{8}$ and $\mathbf{9}$, indicating that $\mathrm{CeO}_{2} \mathrm{NPs}$ interaction with the tested pathogens results in cell damage. It can be observed that the bacterial growth was inhibited from the first hour.

A feasible mechanism of action can be explained by the fact that the $\mathrm{CeO}_{2} \mathrm{NPs}$ are carrying positive charges, and the bacteria are charged negatively, inducing electromagnetic attraction. This attraction ensures direct contact between nanoparticles and bacteria, leading to oxidation and bacterial cellular death.

\section{Conclusions}

Cerium oxide nanoparticles have been designed through a wet chemical method by using the simultaneous addition of reactants (WCS-SimAdd). A better understanding of the decomposition mechanism for as-obtained oxalate precipitate was achieved by DTA-TG and FTIR analyses. The cubic fluorite structure of the cerium oxide nanoparticles was determined by XRD and Raman spectroscopy. TEM and DLS revealed the morphology, showing that the sizes are in the range of 5-20 nm, with pseudospherical shapes and a lower tendency to form aggregates. The oxygen vacancies and formation of $\mathrm{Ce}^{3+}$ evidenced by Raman and UV-Vis spectroscopies are correlated to the particle low-dimensionality. Experiments prove that the synthetized $\mathrm{CeO}_{2} \mathrm{NPs}$ exhibit excellent antibacterial activity against the five tested bacterial species: E. coli, S. typhimurium, L. monocytogenes, S. aureus, and B. cereus. Low MIC values were registered, a result that suggests the suitable antibacterial characteristics of $\mathrm{CeO}_{2} \mathrm{NPs}$. Antibacterial action is attributable to the direct interaction between the cerium oxide nanoparticles and 
the bacteria which induces the cellular death of these pathogens. In overview, this study evidenced the potential antibacterial property of cerium oxide nanoparticles, a fact that leads to new approaches in the development of biomedical and food applications. Further studies, such as long-term treatment, are important for a better understanding and the application of $\mathrm{CeO}_{2} \mathrm{NPs}$ in various antibacterial applications. Consequently, the present study offers a bone substitute material with the combined properties of $\mathrm{CeO}_{2} \mathrm{NPs}$ for the treatment of osteomyelitis.

\section{Declarations}

\section{Conflict of the interest}

None

\section{Acknowledgments}

This research was funded by the frame of Key Natural Science Project of Bengbu Medical College (Project NO. BYKY2019034ZD).

\section{Author Contributions}

Xiusong Dai, Xiaopan Wang, Xiaotian Chen, Longfei Ye -Methodology, Resources, Writing and Manuscript preparation.

\section{Min Wu- Supervision.}

\section{References}

[1] L. Peng, Y. Luo, X. Huang, Z. Li, Carcinogenesis and precancerosis transformation of chronic osteomyelitis: 6 cases report and literature review, Med. Hypotheses. 140 (2020) 109643. https://doi.org/https://doi.org/10.1016/j.mehy.2020.109643.

[2] D.D. Mais, S. Hackman, J. Ross, Histopathologic findings in culture-positive secondary osteomyelitis, Ann. Diagn. Pathol. 50 (2021) 151661. https://doi.org/https://doi.org/10.1016/j.anndiagpath.2020.151661.

[3] G. Ak, Ü.F. Bozkaya, H. Yılmaz, Ö. Sarı Turgut, İ. Bilgin, C. Tomruk, Y. Uyanıkgil, Ş. Hamarat Şanlıer, An intravenous application of magnetic nanoparticles for osteomyelitis treatment: An efficient alternative, Int. J. Pharm. 592 (2021) 119999. https://doi.org/https://doi.org/10.1016/j.jpharm.2020.119999.

[4] A. Llewellyn, J. Kraft, C. Holton, M. Harden, M. Simmonds, Imaging for detection of osteomyelitis in people with diabetic foot ulcers: A systematic review and meta-analysis, Eur. J. Radiol. 131 (2020) 109215. https://doi.org/https://doi.org/10.1016/j.ejrad.2020.109215. 
[5] D. Muthu, M. Gowri, G. Suresh Kumar, V.S. Kattimani, E.K. Girija, Repurposing of antidepression drug sertraline for antimicrobial activity against Staphylococcus aureus: a potential approach for the treatment of osteomyelitis, New J. Chem. 43 (2019) 5315-5324. https://doi.org/10.1039/C8NJ06297H.

[6] A.M. Ramirez, S.D. Byrum, K.E. Beenken, C. Washam, R.D. Edmondson, S.G. Mackintosh, H.J. Spencer, A.J. Tackett, M.S. Smeltzer, Exploiting Correlations between Protein Abundance and the Functional Status of saeRS and sarA To Identify Virulence Factors of Potential Importance in the Pathogenesis of Staphylococcus aureus Osteomyelitis, ACS Infect. Dis. 6 (2020) 237-249. https://doi.org/10.1021/acsinfecdis.9b00291.

[7] P.P. Sedghizadeh, S. Sun, A.F. Junka, E. Richard, K. Sadrerafi, S. Mahabady, N. Bakhshalian, N. Tjokro, M. Bartoszewicz, M. Oleksy, P. Szymczyk, M.W. Lundy, J.D. Neighbors, R.G.G. Russell, C.E. McKenna, F.H. Ebetino, Design, Synthesis, and Antimicrobial Evaluation of a Novel Bone-Targeting Bisphosphonate-Ciprofloxacin Conjugate for the Treatment of Osteomyelitis Biofilms, J. Med. Chem. 60 (2017) 2326-2343. https://doi.org/10.1021/acs.jmedchem.6b01615.

[8] J. Zhang, M. Zhao, X. Tian, X. Lv, Z. Chen, K. Zhou, X. Ren, P. Zhang, X. Mei, Protein-mediated mineralization of edaravone into injectable, $\mathrm{pH}$-sensitive microspheres used for potential minimally invasive treatment of osteomyelitis, New J. Chem. 42 (2018) 5447-5455. https://doi.org/10.1039/C7NJ04745B.

[9] N. Hassani Besheli, F. Mottaghitalab, M. Eslami, M. Gholami, S.C. Kundu, D.L. Kaplan, M. Farokhi, Sustainable Release of Vancomycin from Silk Fibroin Nanoparticles for Treating Severe Bone Infection in Rat Tibia Osteomyelitis Model, ACS Appl. Mater. Interfaces. 9 (2017) 5128-5138. https://doi.org/10.1021/acsami.6b14912.

[10] T. Wu, Q. Zhang, W. Ren, X. Yi, Z. Zhou, X. Peng, X. Yu, M. Lang, Controlled release of gentamicin from gelatin/genipin reinforced beta-tricalcium phosphate scaffold for the treatment of osteomyelitis, J. Mater. Chem. B. 1 (2013) 3304-3313. https://doi.org/10.1039/C3TB20261E.

[11] G.S. Kumar, R. Govindan, E.K. Girija, In situ synthesis, characterization and in vitro studies of ciprofloxacin loaded hydroxyapatite nanoparticles for the treatment of osteomyelitis, J. Mater. Chem. B. 2 (2014) 5052-5060. https://doi.org/10.1039/C4TB00339J.

[12] T. Zhang, Q. Wei, H. Zhou, W. Zhou, D. Fan, X. Lin, Z. Jing, H. Cai, Y. Cheng, X. Liu, W. Li, C. Song, Y. Tian, N. Xu, Y. Zheng, Z. Liu, Sustainable release of vancomycin from micro-arc oxidised 3D-printed porous Ti6Al4V for treating methicillin-resistant Staphylococcus aureus bone infection and enhancing osteogenesis in a rabbit tibia osteomyelitis model, Biomater. Sci. 8 (2020) 3106-3115. https://doi.org/10.1039/C9BM01968E.

[13] S. Busi, J. Rajkumari, Microbially synthesized nanoparticles as next generation antimicrobials: scope and applications, Nanoparticles Pharmacother. (2019) 485-524. https://doi.org/10.1016/B978-012-816504-1.00008-9. 
[14] G.S. Dijksteel, M.M.W. Ulrich, M. Vlig, P.H. Nibbering, R.A. Cordfunke, J.W. Drijfhout, E. Middelkoop, B.K.H.L. Boekema, Potential factors contributing to the poor antimicrobial efficacy of SAAP-148 in a rat wound infection model, Ann. Clin. Microbiol. Antimicrob. 18 (2019) 38. https://doi.org/10.1186/s12941019-0336-7.

[15] K. Madhumathi, P.T. Sudheesh Kumar, S. Abhilash, V. Sreeja, H. Tamura, K. Manzoor, S. V Nair, R. Jayakumar, Development of novel chitin/nanosilver composite scaffolds for wound dressing applications, J. Mater. Sci. Mater. Med. 21 (2010) 807-813. https://doi.org/10.1007/s10856-009-3877-z.

[16] H. Kalita, A. Hazarika, R. Kandimalla, S. Kalita, R. Devi, Development of banana (Musa balbisiana) pseudo stem fiber as a surgical bio-tool to avert post-operative wound infections, RSC Adv. 8 (2018) 36791-36801. https://doi.org/10.1039/C8RA04470H.

[17] I.K. Sani, S. Pirsa, Ş. Tağı, Preparation of chitosan/zinc oxide/Melissa offıcinalis essential oil nanocomposite film and evaluation of physical, mechanical and antimicrobial properties by response surface method, Polym. Test. 79 (2019) 106004.

https://doi.org/https://doi.org/10.1016/j.polymertesting.2019.106004.

[18] L.M. Estes, P. Singha, S. Singh, T.S. Sakthivel, M. Garren, R. Devine, E.J. Brisbois, S. Seal, H. Handa, Characterization of a nitric oxide (NO) donor molecule and cerium oxide nanoparticle (CNP) interactions and their synergistic antimicrobial potential for biomedical applications, J. Colloid Interface Sci. 586 (2021) 163-177. https://doi.org/https://doi.org/10.1016/j.jcis.2020.10.081.

[19] S. Ghuman, B. Ncube, J.F. Finnie, L.J. McGaw, E. Mfotie Njoya, R.M. Coopoosamy, J. Van Staden, Antioxidant, anti-inflammatory and wound healing properties of medicinal plant extracts used to treat wounds and dermatological disorders, South African J. Bot. 126 (2019) 232-240. https://doi.org/https://doi.org/10.1016/j.sajb.2019.07.013.

[20] A. Nabikhan, K. Kandasamy, A. Raj, N.M. Alikunhi, Synthesis of antimicrobial silver nanoparticles by callus and leaf extracts from saltmarsh plant, Sesuvium portulacastrum L., Colloids Surfaces B Biointerfaces. 79 (2010) 488-493. https://doi.org/https://doi.org/10.1016/j.colsurfb.2010.05.018.

[21] R.A. Ferreira, S. Martins-Dias, Purification of plant complex protein extracts in non-denaturing conditions by in-solution isoelectric focusing, Anal. Biochem. 509 (2016) 100-103. https://doi.org/https://doi.org/10.1016/j.ab.2016.07.004.

[22] H. Agarwal, A. Nakara, V.K. Shanmugam, Anti-inflammatory mechanism of various metal and metal oxide nanoparticles synthesized using plant extracts: A review, Biomed. Pharmacother. 109 (2019) 2561-2572. https://doi.org/https://doi.org/10.1016/j.biopha.2018.11.116.

[23] G.K. Weldegebrieal, Synthesis method, antibacterial and photocatalytic activity of $\mathrm{ZnO}$ nanoparticles for azo dyes in wastewater treatment: A review, Inorg. Chem. Commun. 120 (2020) 108140. https://doi.org/https://doi.org/10.1016/j.inoche.2020.108140. 
[24] L.F. González Arbeláez, A. Ciocci Pardo, J.C. Fantinelli, G.R. Schinella, S.M. Mosca, J.-L. Ríos, Cardioprotection and natural polyphenols: an update of clinical and experimental studies, Food Funct. 9 (2018) 6129-6145. https://doi.org/10.1039/C8F001307A.

[25] M. Ibrar, M.A. Khan, Abdullah, M. Nisar, M. Khan, Evaluation of Paeonia emodi for its cardioprotective potentials: An investigative study towards possible mechanism, J. Ethnopharmacol. 231 (2019) 57-65. https://doi.org/10.1016/j.jep.2018.10.041.

[26] K.R. Rakhimol, S. Thomas, N. Kalarikkal, K. Jayachandran, Casein mediated synthesis of stabilized metal/metal-oxide nanoparticles with varied surface morphology through pH alteration, Mater. Chem. Phys. 246 (2020) 122803. https://doi.org/https://doi.org/10.1016/j.matchemphys.2020.122803.

[27] I. Galván Márquez, M. Ghiyasvand, A. Massarsky, M. Babu, B. Samanfar, K. Omidi, T.W. Moon, M.L. Smith, A. Golshani, Zinc oxide and silver nanoparticles toxicity in the baker's yeast, Saccharomyces cerevisiae, PLoS One. 13 (2018) e0193111. https://doi.org/10.1371/journal.pone.0193111.

[28] M. Santha Moorthy, B. Subramanian, M. Panchanathan, S. Mondal, H. Kim, K.D. Lee, J. Oh, Fucoidan-coated core-shell magnetic mesoporous silica nanoparticles for chemotherapy and magnetic hyperthermia-based thermal therapy applications, New J. Chem. 41 (2017) 15334-15346. https://doi.org/10.1039/c7nj03211k.

[29] Z. Hussain, J.A. Khan, H. Anwar, N. Andleeb, S. Murtaza, A. Ashar, I. Arif, Synthesis, characterization, and pharmacological evaluation of zinc oxide nanoparticles formulation, Toxicol. Ind. Health. 34 (2018) 753-763. https://doi.org/10.1177/0748233718793508.

[30] A.Y. Estevez, M. Ganesana, J.F. Trentini, J.E. Olson, G. Li, Y.O. Boateng, J.M. Lipps, S.E.R. Yablonski, W.T. Donnelly, J.C. Leiter, J.S. Erlichman, Antioxidant Enzyme-Mimetic Activity and Neuroprotective Effects of Cerium Oxide Nanoparticles Stabilized with Various Ratios of Citric Acid and EDTA, Biomolecules. 9 (2019). https://doi.org/10.3390/biom9100562.

[31] M. Khatami, M. Sarani, F. Mosazadeh, M. Rajabalipour, A. Izadi, M. Abdollahpour-Alitappeh, M.A. Lima Nobre, F. Borhani, Nickel-Doped Cerium Oxide Nanoparticles: Green Synthesis Using Stevia and Protective Effect against Harmful Ultraviolet Rays, Molecules. 24 (2019).

https://doi.org/10.3390/molecules24244424.

[32] G. Sener, S.A. Hilton, M.J. Osmond, C. Zgheib, J.P. Newsom, L. Dewberry, S. Singh, T.S. Sakthivel, S. Seal, K.W. Liechty, M.D. Krebs, Injectable, self-healable zwitterionic cryogels with sustained microRNA cerium oxide nanoparticle release promote accelerated wound healing, Acta Biomater. 101 (2020) 262272. https://doi.org/https://doi.org/10.1016/j.actbio.2019.11.014.

[33] X. Huang, L.-D. Li, G.-M. Lyu, B.-Y. Shen, Y.-F. Han, J.-L. Shi, J.-L. Teng, L. Feng, S.-Y. Si, J.-H. Wu, Y.-J. Liu, L.-D. Sun, C.-H. Yan, Chitosan-coated cerium oxide nanocubes accelerate cutaneous wound healing 
by curtailing persistent inflammation, Inorg. Chem. Front. 5 (2018) 386-393. https://doi.org/10.1039/C7QI00707H.

[34] P. Eriksson, A.A. Tal, A. Skallberg, C. Brommesson, Z. Hu, R.D. Boyd, W. Olovsson, N. Fairley, I.A. Abrikosov, X. Zhang, K. Uvdal, Cerium oxide nanoparticles with antioxidant capabilities and gadolinium integration for MRI contrast enhancement, Sci. Rep. 8 (2018) 6999. https://doi.org/10.1038/s41598-01825390-z.

[35] C. Zgheib, S.A. Hilton, L.C. Dewberry, M.M. Hodges, S. Ghatak, J. Xu, S. Singh, S. Roy, C.K. Sen, S. Seal, K.W. Liechty, Use of Cerium Oxide Nanoparticles Conjugated with MicroRNA-146a to Correct the Diabetic Wound Healing Impairment, J. Am. Coll. Surg. 228 (2019) 107-115. https://doi.org/https://doi.org/10.1016/j.jamcollsurg.2018.09.017.

[36] Y. Xue, Q. Luan, D. Yang, X. Yao, K. Zhou, Direct evidence for hydroxyl radical scavenging activity of cerium oxide nanoparticles, J. Phys. Chem. C. 115 (2011) 4433-4438.

[37] Y. Song, W. Wei, X. Qu, Colorimetric Biosensing Using Smart Materials, Adv. Mater. 23 (2011) 42154236. https://doi.org/10.1002/adma.201101853.

[38] M. Mauro, M. Crosera, M. Monai, T. Montini, P. Fornasiero, M. Bovenzi, G. Adami, G. Turco, F.L. Filon, Cerium Oxide Nanoparticles Absorption through Intact and Damaged Human Skin, Molecules. 24 (2019). https://doi.org/10.3390/molecules24203759.

[39] A. Symington, M. Molinari, S. Moxon, J. Flitcroft, D. Sayle, S.C. Parker, Strongly Bound Surface Water Affects the Shape Evolution of Cerium Oxide Nanoparticles, (2019). https://doi.org/10.26434/chemrxiv.9247709.v2.

[40] T. Pirmohamed, J.M. Dowding, S. Singh, B. Wasserman, E. Heckert, A.S. Karakoti, J.E.S. King, S. Seal, W.T. Self, Nanoceria exhibit redox state-dependent catalase mimetic activity, Chem. Commun. 46 (2010) 2736-2738. https://doi.org/10.1039/B922024K.

[41] A. Kumar, S. Das, P. Munusamy, W. Self, D.R. Baer, D.C. Sayle, S. Seal, Behavior of nanoceria in biologically-relevant environments, Environ. Sci. Nano. 1 (2014) 516-532. https://doi.org/10.1039/C4EN00052H.

[42] H. Muthukumar, S.K. Palanirajan, M.K.S.S.N. Gummadi, Plant extract mediated synthesis enhanced the functional properties of silver ferrite nanoparticles over chemical mediated synthesis, Biotechnol. Reports. (2020) e00469. https://doi.org/https://doi.org/10.1016/j.btre.2020.e00469.

[43] B. Singh, A. Dhiman, Designing bio-mimetic moxifloxacin loaded hydrogel wound dressing to improve antioxidant and pharmacology properties, RSC Adv. 5 (2015) 44666-44678. https://doi.org/10.1039/C5RA06857F. 
[44] D.A. Kumar, V. Palanichamy, S.M. Roopan, Green synthesis of silver nanoparticles using Alternanthera dentata leaf extract at room temperature and their antimicrobial activity, Spectrochim. Acta Part A Mol. Biomol. Spectrosc. 127 (2014) 168-171. https://doi.org/https://doi.org/10.1016/j.saa.2014.02.058.

[45] Y. Liang, X. Zhao, T. Hu, B. Chen, Z. Yin, P.X. Ma, B. Guo, Adhesive Hemostatic Conducting Injectable Composite Hydrogels with Sustained Drug Release and Photothermal Antibacterial Activity to Promote Full-Thickness Skin Regeneration During Wound Healing, Small. 15 (2019) 1900046. https://doi.org/https://doi.org/10.1002/smll.201900046.

[46] A. V Ramesh, D.R. Devi, G. Battu, K. Basavaiah, A Facile plant mediated synthesis of silver nanoparticles using an aqueous leaf extract of Ficus hispida Linn. f. for catalytic, antioxidant and antibacterial applications, South African J. Chem. Eng. 26 (2018) 25-34. https://doi.org/https://doi.org/10.1016/j.sajce.2018.07.001.

[47] M. Shi, H. Zhang, T. Song, X. Liu, Y. Gao, J. Zhou, Y. Li, Sustainable Dual Release of Antibiotic and Growth Factor from pH-Responsive Uniform Alginate Composite Microparticles to Enhance Wound Healing, ACS Appl. Mater. Interfaces. 11 (2019) 22730-22744. https://doi.org/10.1021/acsami.9b04750.

[48] S.S. Hosseini Salekdeh, H. Daemi, M. Zare-Gachi, S. Rajabi, F. Bazgir, N. Aghdami, M.S. Nourbakhsh, H. Baharvand, Assessment of the Efficacy of Tributylammonium Alginate Surface-Modified Polyurethane as an Antibacterial Elastomeric Wound Dressing for both Noninfected and Infected FullThickness Wounds, ACS Appl. Mater. Interfaces. 12 (2020) 3393-3406. https://doi.org/10.1021/acsami.9b18437.

[49] W.R. Rolim, J.C. Pieretti, D.L.S. Renó, B.A. Lima, M.H.M. Nascimento, F.N. Ambrosio, C.B. Lombello, M. Brocchi, A.C.S. de Souza, A.B. Seabra, Antimicrobial Activity and Cytotoxicity to Tumor Cells of Nitric Oxide Donor and Silver Nanoparticles Containing PVA/PEG Films for Topical Applications, ACS Appl. Mater. Interfaces. 11 (2019) 6589-6604. https://doi.org/10.1021/acsami.8b19021.

[50] M. Li, C. Zhang, G. Chen, L. Nahar, S.D. Sarker, M. Guo, Headspace gas chromatographic method for antimicrobial screening: Minimum inhibitory concentration determination, J. Pharm. Biomed. Anal. 181 (2020) 113122. https://doi.org/https://doi.org/10.1016/j.jpba.2020.113122.

[51] L. Shao, C. You, J. Cao, Y. Jiang, Y. Liu, Q. Liu, High treatment failure rate is better explained by resistance gene detection than by minimum inhibitory concentration in patients with urogenital Chlamydia trachomatis infection, Int. J. Infect. Dis. 96 (2020) 121-127. https://doi.org/https://doi.org/10.1016/j.ijid.2020.03.015.

[52] S. Hemati, E. Kouhsari, N. Sadeghifard, A. Maleki, N. Omidi, Z. Mahdavi, I. Pakzad, Sub-minimum inhibitory concentrations of biocides induced biofilm formation in Pseudomonas aeruginosa, New Microbes New Infect. 38 (2020) 100794. https://doi.org/https://doi.org/10.1016/j.nmni.2020.100794. 
[53] Y. Liu, J.H. Moore, G.L. Kolling, J.S. McGrath, J.A. Papin, N.S. Swami, Minimum bactericidal concentration of ciprofloxacin to Pseudomonas aeruginosa determined rapidly based on pyocyanin secretion, Sensors Actuators B Chem. 312 (2020) 127936.

https://doi.org/https://doi.org/10.1016/j.snb.2020.127936.

[54] D. Knaack, E.A. Idelevich, N. Schleimer, S. Molinaro, A. Kriegeskorte, G. Peters, K. Becker, Bactericidal activity of bacteriophage endolysin HY-133 against Staphylococcus aureus in comparison to other antibiotics as determined by minimum bactericidal concentrations and time-kill analysis, Diagn. Microbiol. Infect. Dis. 93 (2019) 362-368.

https://doi.org/https://doi.org/10.1016/j.diagmicrobio.2018.11.005.

[55] G.S. Hall, K. Pratt-Rippin, D.M. Meisler, J.A. Washington, T.J. Roussel, D. Miller, Minimum bactericidal concentrations of Propionibacterium acnes isolates from cases of chronic endophthalmitis, Diagn. Microbiol. Infect. Dis. 21 (1995) 187-190. https://doi.org/https://doi.org/10.1016/07328893(95)00040-H.

[56] M. Kaushal, T.S. Lobana, L. Nim, J. Kaur, R. Bala, G. Hundal, D.S. Arora, I. Garcia-Santos, C.E. Duff, J.P. Jasinski, Synthesis, structures, antimicrobial activity and biosafety evaluation of pyridine-2-

formaldehyde-N-susbtituted-thiosemicarbazonates of copper(ii), New J. Chem. 42 (2018) 15879-15894. https://doi.org/10.1039/C8NJ03619E.

[57] P. Suyana, S. Nishanth Kumar, N. Madhavan, B.S. Dileep Kumar, B.N. Nair, A.P. Mohamed, K.G.K. Warrier, U.S. Hareesh, Reactive oxygen species (ROS) mediated enhanced anti-candidal activity of ZnSZnO nanocomposites with low inhibitory concentrations, RSC Adv. 5 (2015) 76718-76728. https://doi.org/10.1039/C5RA13316E.

[58] S. Pathak, M.K. Ghosh, M. Mandal, V. Mandal, A. Bhattacharyya, T.K. Ghorai, Synthesis of a new acetate bridged $\mathrm{Cu}(\mathrm{ii})$ building block generated 1D polymer and studies on structural, magnetic, antibacterial and anticancer properties, New J. Chem. 43 (2019) 2019-2029. https://doi.org/10.1039/C8NJ04937H.

[59] K. Gadani, D. Dhruv, Z. Joshi, H. Boricha, K.N. Rathod, M.J. Keshvani, N.A. Shah, P.S. Solanki, Transport properties and electroresistance of a manganite based heterostructure: role of the manganitemanganite interface, Phys. Chem. Chem. Phys. 18 (2016) 17740-17749.

https://doi.org/10.1039/C6CP02053D.

[60] C.B. Anders, J.E. Eixenberger, N.A. Franco, R.J. Hermann, K.D. Rainey, J.J. Chess, A. Punnoose, D.G. Wingett, ZnO nanoparticle preparation route influences surface reactivity, dissolution and cytotoxicity, Environ. Sci. Nano. 5 (2018) 572-588. https://doi.org/10.1039/C7EN00888K.

[61] W. Huang, C. Li, L. Gao, Y. Zhang, Y. Wang, Z.N. Huang, T. Chen, L. Hu, H. Zhang, Emerging black phosphorus analogue nanomaterials for high-performance device applications, J. Mater. Chem. C. 8 (2020) 1172-1197. https://doi.org/10.1039/C9TC05558D. 
Figures
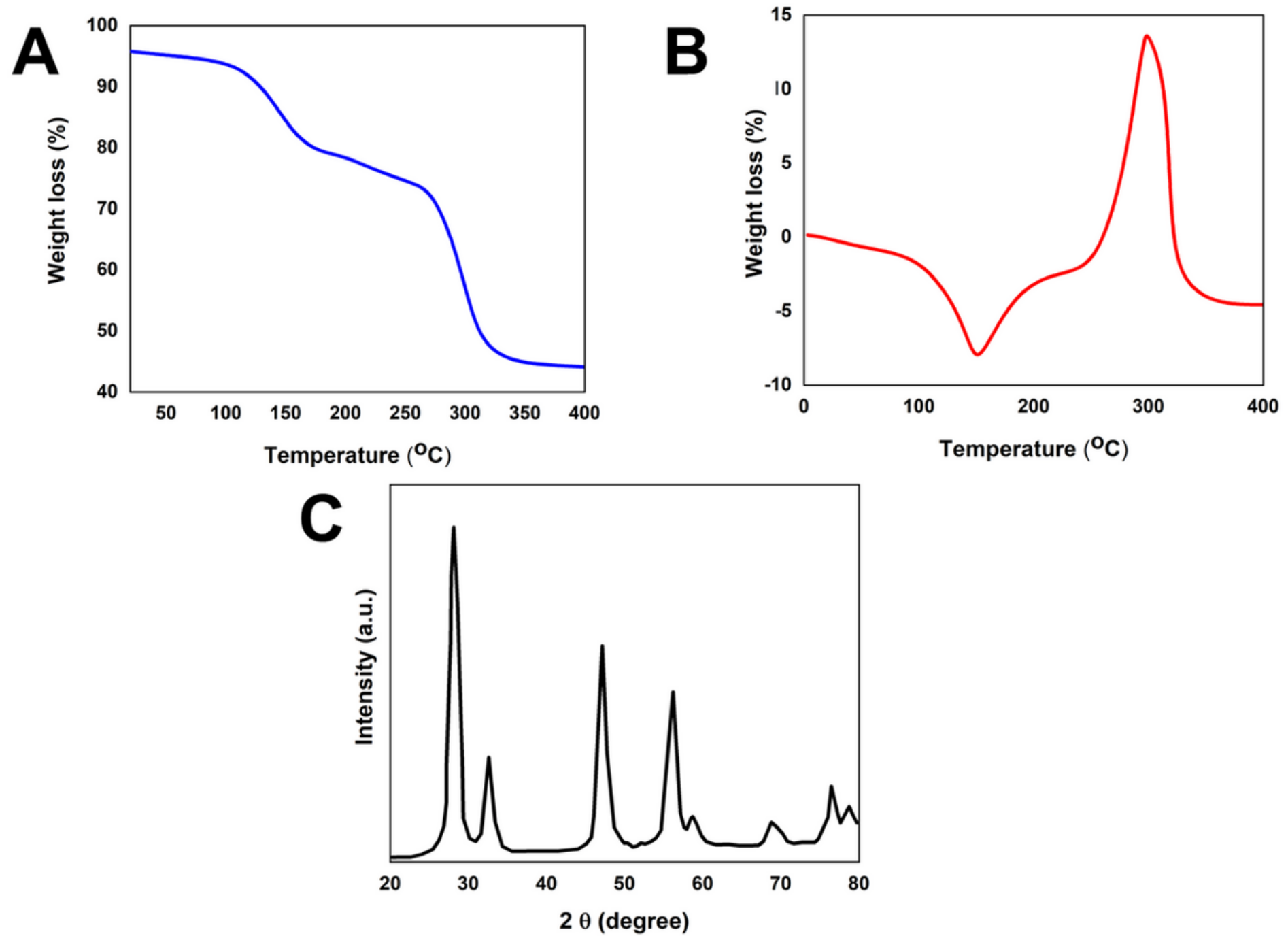

Figure 1

(a) Thermal analysis of the cerium oxalate precursor (total theoretical weight loss is $52.49 \%$ ). (b) XRD pattern recorded at room temperature for $\mathrm{CeO} 2 \mathrm{NPs}$. 
A

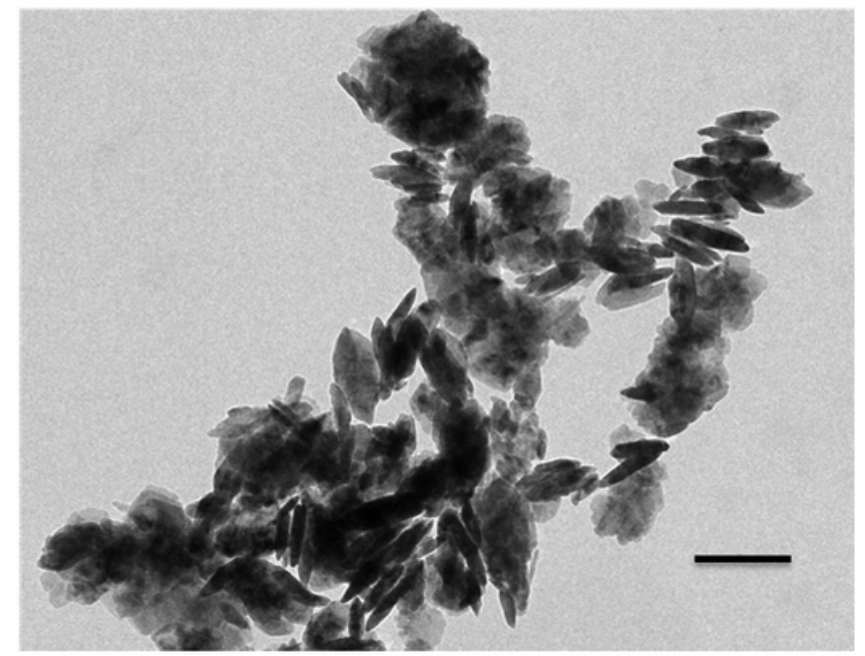

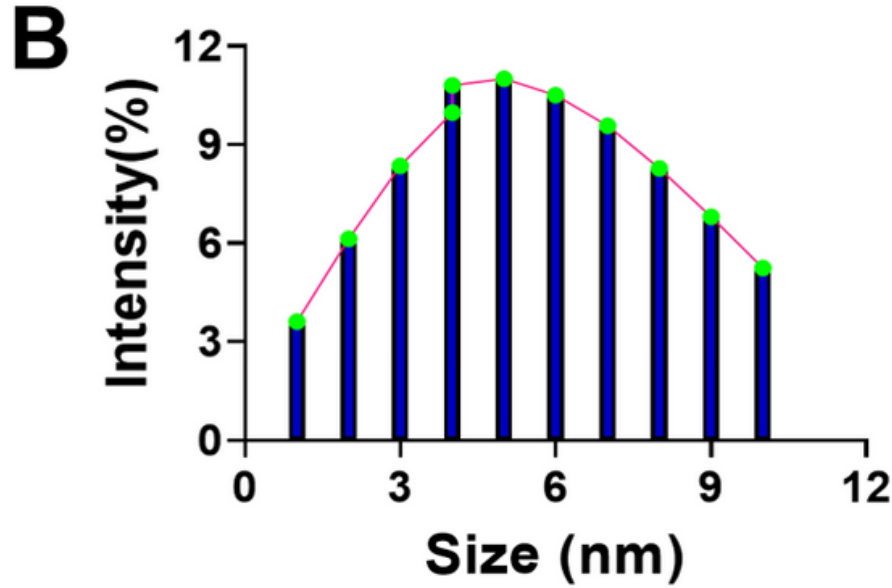

Figure 2

TEM and HRTEM images (a,b) and DLS measurement (c) of thermally treated CeO2 NPs. The scales are 1 $\mu \mathrm{m}(\mathrm{a})$ and $20 \mathrm{~nm}(\mathrm{~b})$.
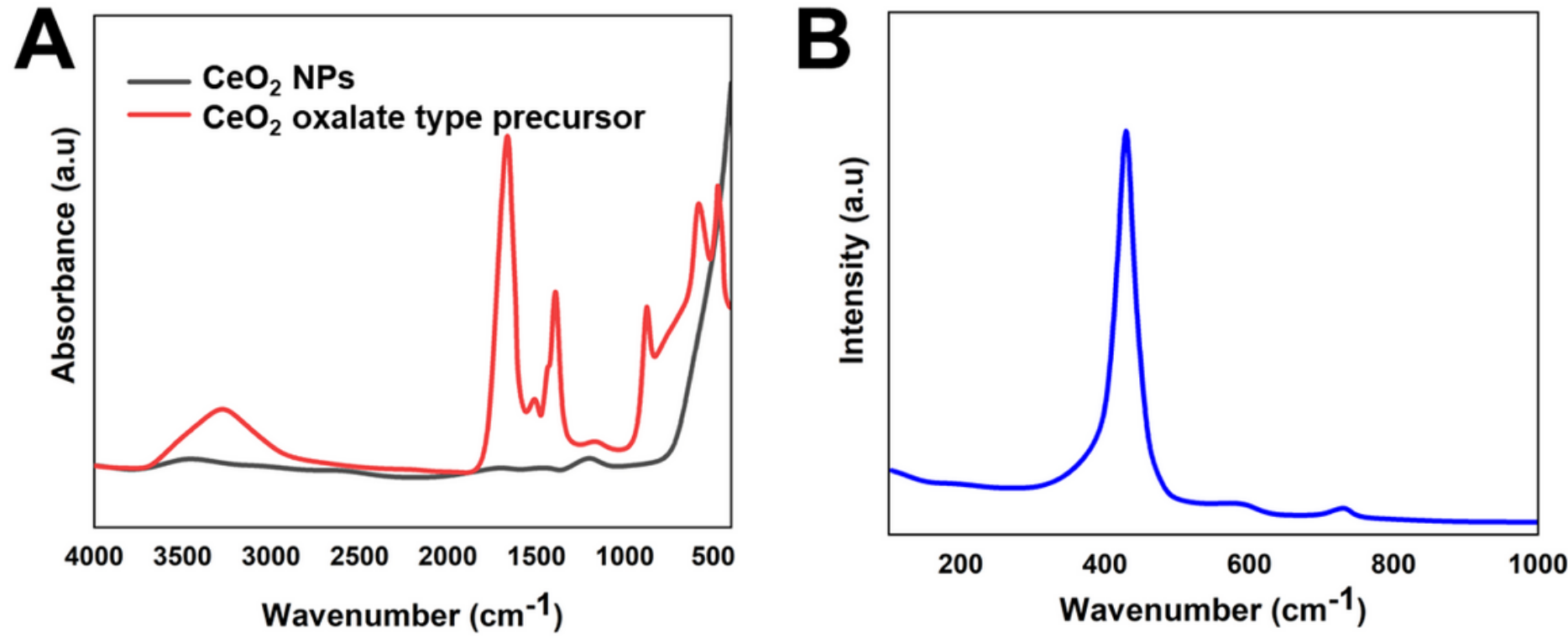

Figure 3

(a) FTIR spectra of cerium oxalate-type precursor and CeO2 NPs (4000-350 cm-1). (b) Raman spectrum of $\mathrm{CeO} 2 \mathrm{NPs}$. 


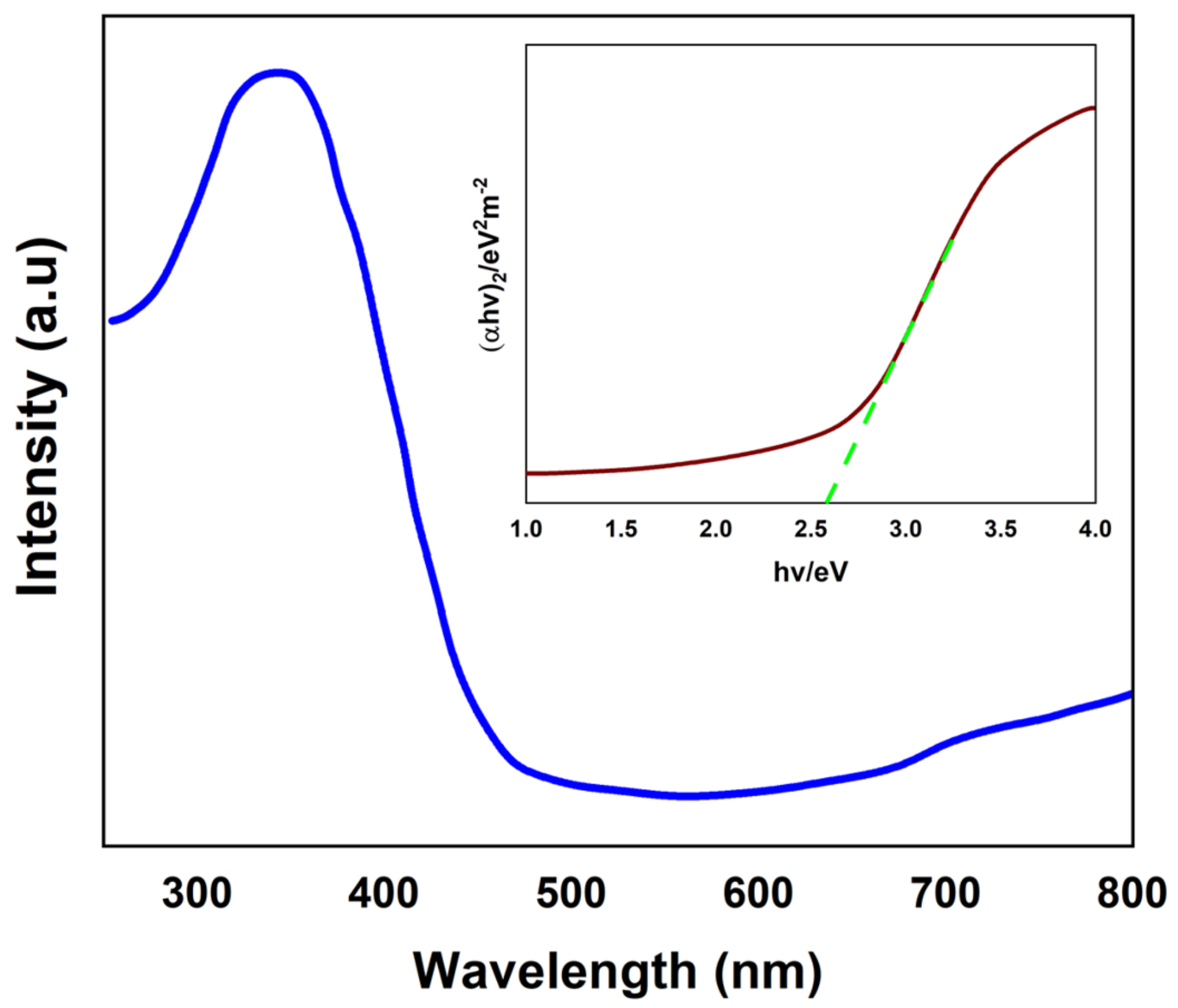

Figure 4

UV-Vis diffuse absorption spectra of the obtained $\mathrm{CeO} 2 \mathrm{NPs}$ and optical band gap determination from the plot of (ahv)2 versus photon energy (ah) the inset. 


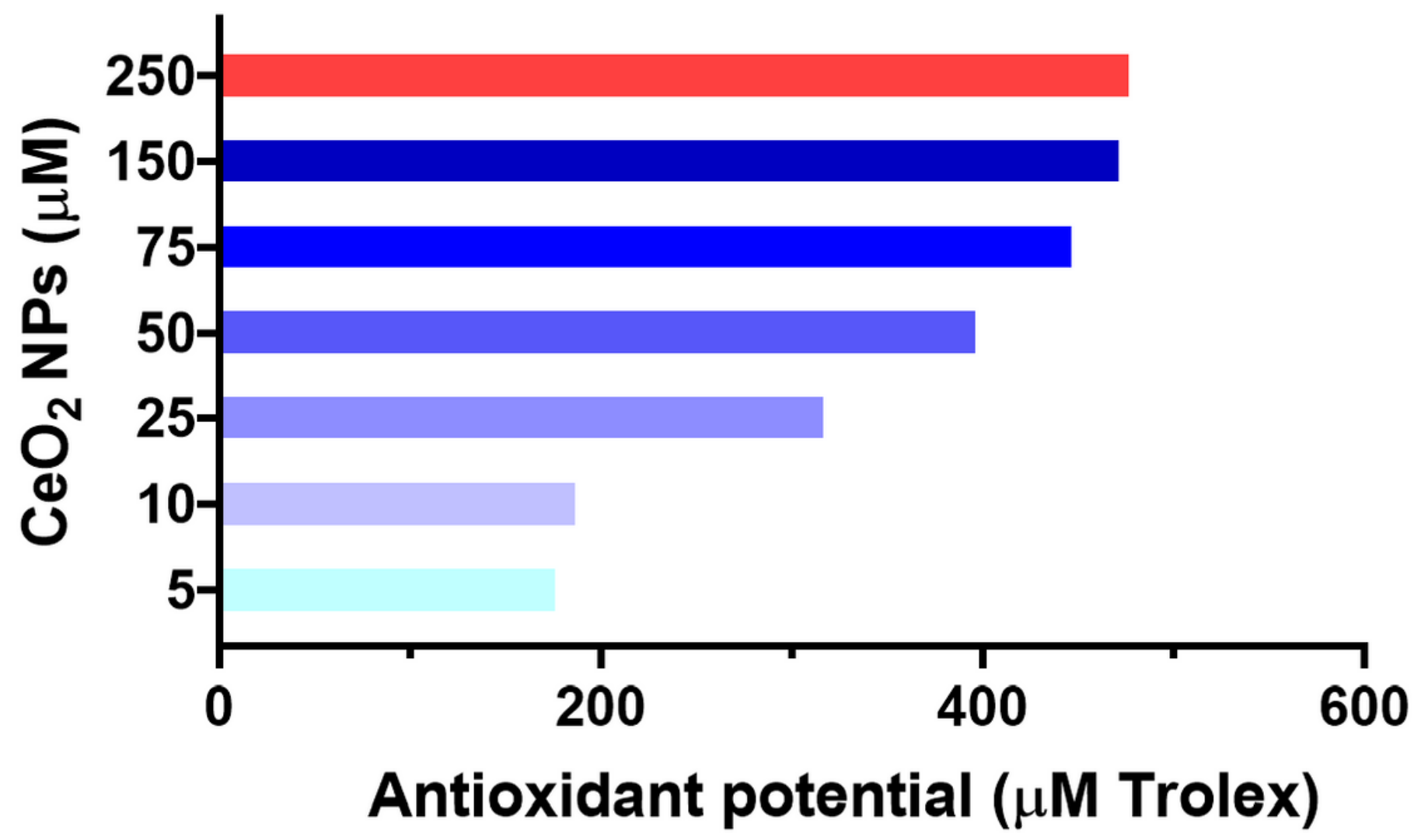

Figure 5

Antioxidant capacity of $\mathrm{CeO} 2 \mathrm{NPs}$ estimated by ABTS--assays (expressed as $\mu \mathrm{mol}$ trolox /g sample).

Control

$\mathrm{CeO}_{2} \mathrm{NPs}(50 \mu \mathrm{g} / \mathrm{mL})$

\section{Escherichia coli}
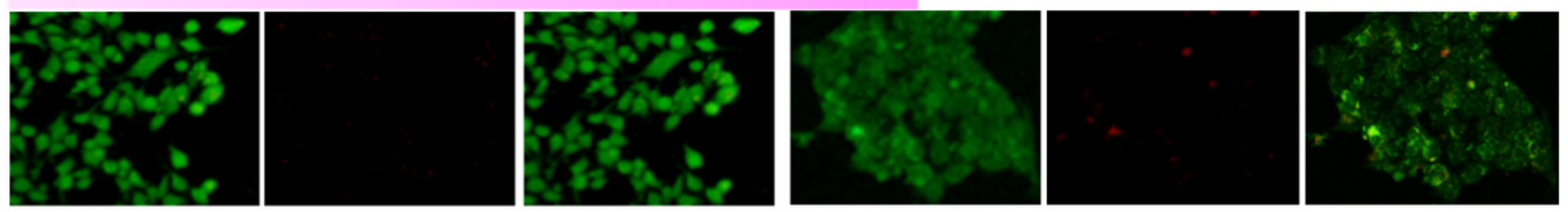

\section{Salmonella typhimurium}
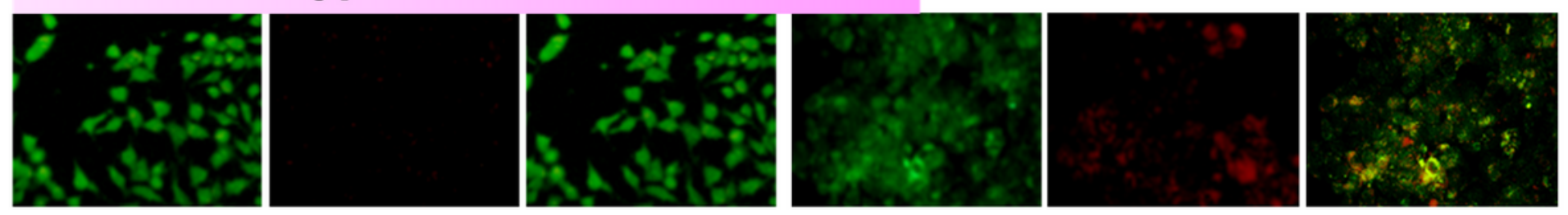

Figure 6 
LIVE/DEAD bacterial viability control (left) and after $24 \mathrm{~h}$ of treatment with $50 \mu \mathrm{g} / \mathrm{mL} \mathrm{CeO2} \mathrm{NPs} \mathrm{(right):}$ Escherichia coli, Salmonella typhimurium. Live cells (expressing SYTO® 9) are shown in green, and dead cells (expressing propidium iodide) are shown in red. (Original magnification: $\times 20$ ).

\section{Control}

\section{$\mathrm{CeO}_{2} \mathrm{NPs}(50 \mu \mathrm{g} / \mathrm{mL})$}

\section{Listeria monocytogenes}
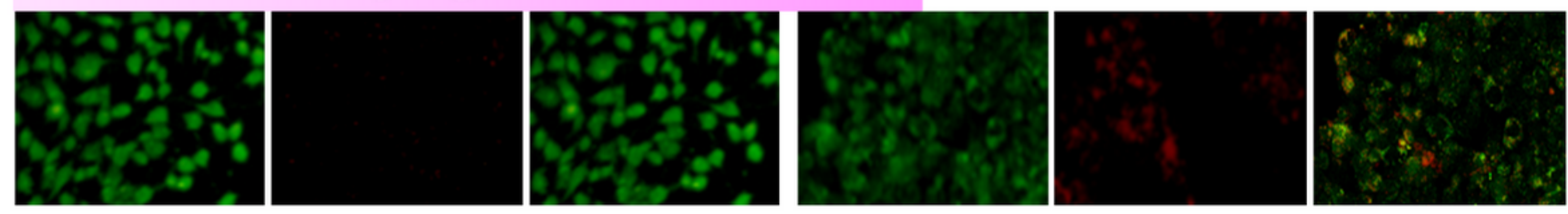

\section{Staphylococcus aureus}
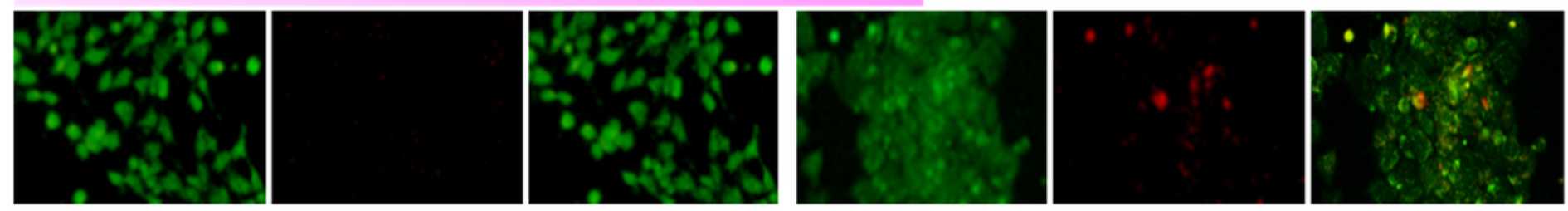

\section{Bacillus cereus}
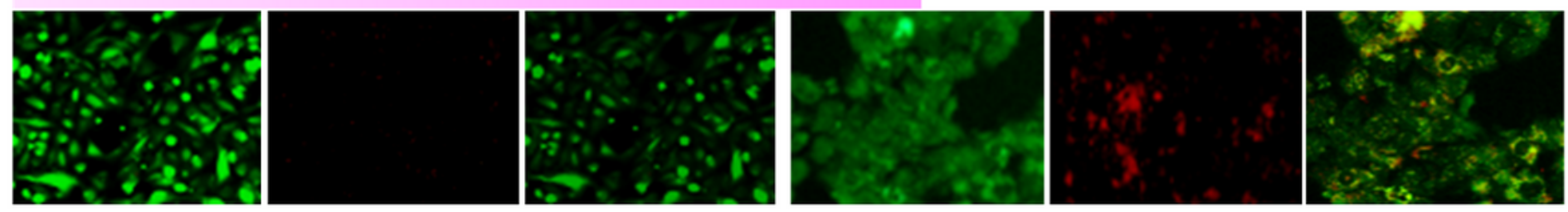

Figure 7

LIVE/DEAD bacterial viability control (left) and after $24 \mathrm{~h}$ of treatment with $50 \mu \mathrm{g} / \mathrm{mL}$ CeO2 NPs (right): Listeria monocytogenes, Staphylococcus aureus, and Bacillus cereus. Live cells are shown in green, and dead cells (expressing propidium iodide) are shown in red. (Original magnification: $\times 20$ ). 


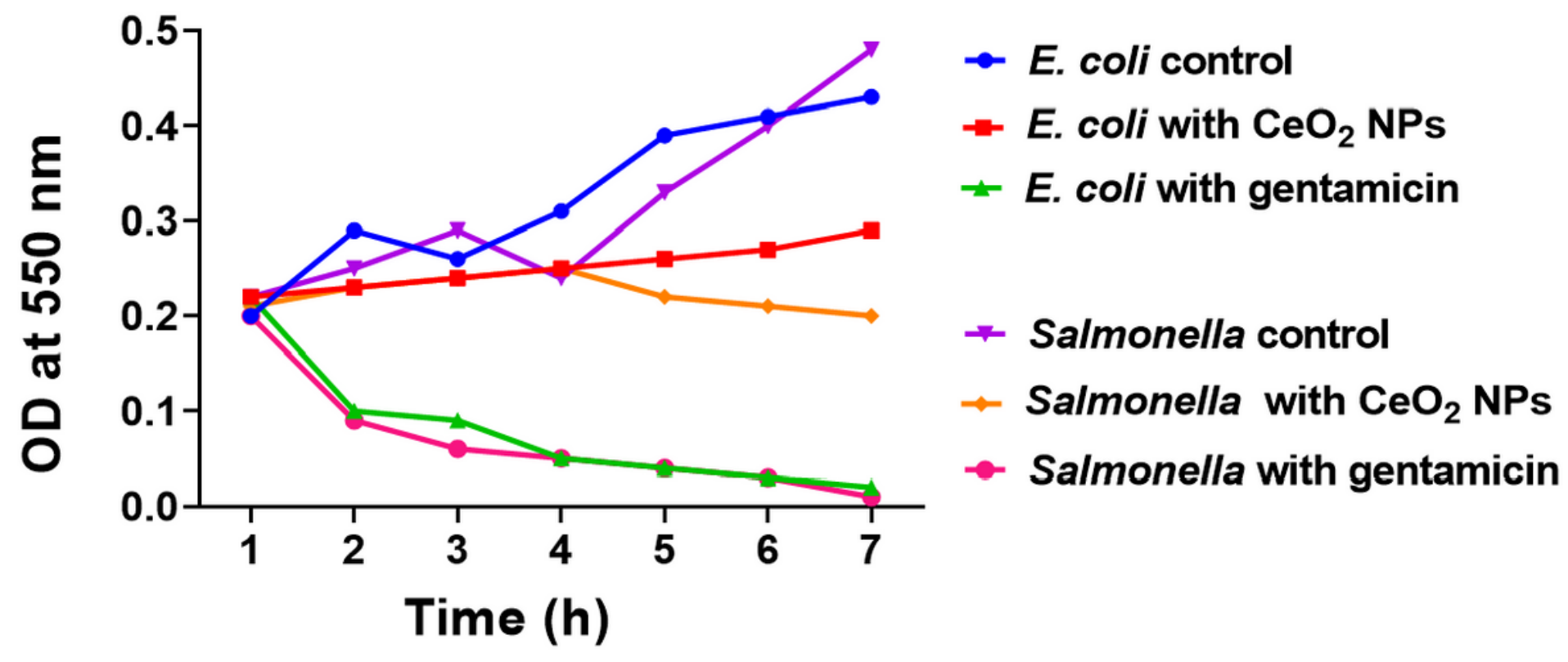

Figure 8

Time kill assay of $\mathrm{CeO} 2$ NPs against the Gram-negative bacteria (E. coli and Salmonella).

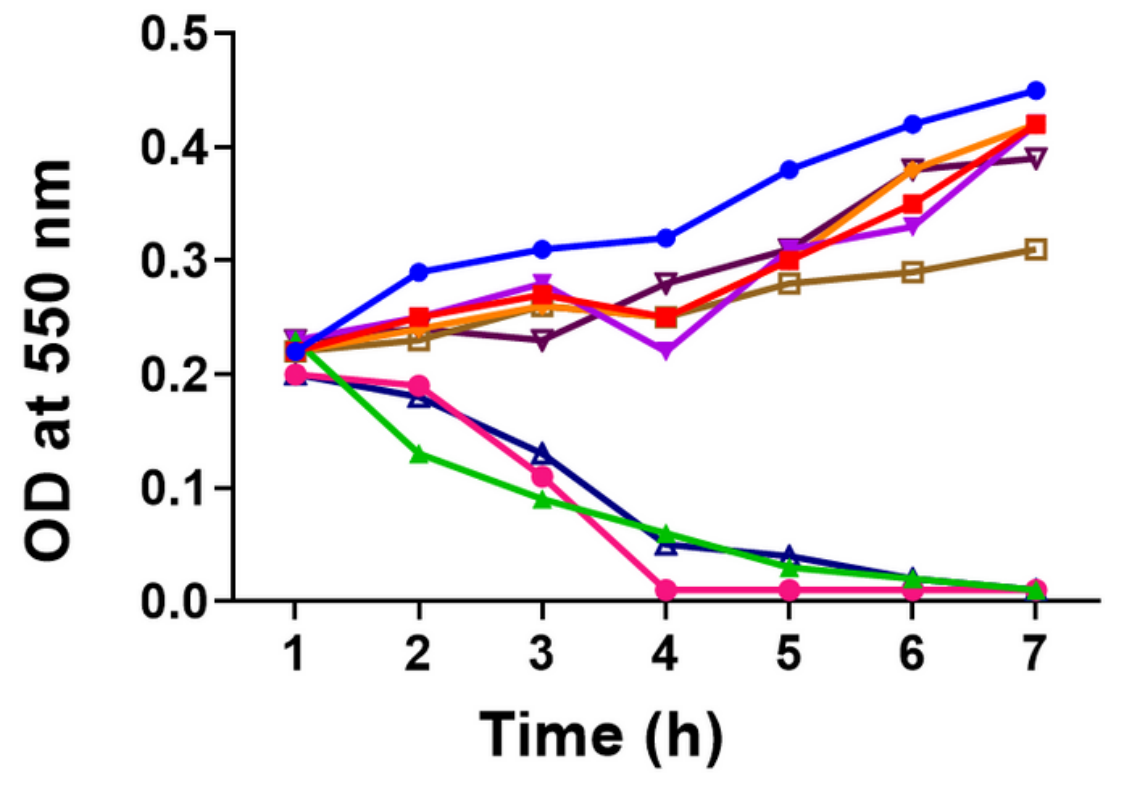

$\rightarrow$ Listeria control

- Listeria with $\mathrm{CeO}_{2}$ NPs

- Listeria with gentamicin

* S. aureus control

$\rightarrow$ S. aureus with $\mathrm{CeO}_{2}$ NPs

- S. aureus with gentamicin

— B. cereus control

$\triangle$ B. cereus with $\mathrm{CeO}_{2} \mathrm{NPs}$

$\rightarrow$ B. cereus with gentamicin

Figure 9

Time kill assay of $\mathrm{CeO} 2$ NPs against the Gram-positive bacteria (Listeria, S. aureus, and B. cereus).

\section{Supplementary Files}


This is a list of supplementary files associated with this preprint. Click to download.

- Graphicalabstract.docx 